University of Nebraska - Lincoln

DigitalCommons@University of Nebraska - Lincoln

\title{
Repeat Organic Dust Exposure-Induced Monocyte Inflammation is Associated with Protein Kinase C Activity
}

Jill A. Poole

Omaha, Neb

Todd A. Wyatt

Omaha, Neb

Susanna G. Von Essen

Omaha, Neb

John Hervert

Omaha, Neb

Conrad Parks

Omaha, Neb

See next page for additional authors

Follow this and additional works at: https://digitalcommons.unl.edu/publichealthresources

Part of the Public Health Commons

Poole, Jill A.; Wyatt, Todd A.; Von Essen, Susanna G.; Hervert, John; Parks, Conrad; Mathisen, Tracy; and Romberger, Debra J., "Repeat Organic Dust Exposure-Induced Monocyte Inflammation is Associated with Protein Kinase C Activity" (2007). Public Health Resources. 56.

https://digitalcommons.unl.edu/publichealthresources/56

This Article is brought to you for free and open access by the Public Health Resources at DigitalCommons@University of Nebraska - Lincoln. It has been accepted for inclusion in Public Health Resources by an authorized administrator of DigitalCommons@University of Nebraska - Lincoln. 


\section{Authors}

Jill A. Poole, Todd A. Wyatt, Susanna G. Von Essen, John Hervert, Conrad Parks, Tracy Mathisen, and Debra J. Romberger 


\title{
Repeat organic dust exposure-induced monocyte inflammation is associated with protein kinase $C$ activity
}

\author{
Jill A. Poole, MD, ${ }^{a, b}$ Todd A. Wyatt, PhD, ${ }^{a, b}$ Susanna G. Von Essen, MD, MPH, ${ }^{a}$ \\ John Hervert, BS, ${ }^{a, b}$ Conrad Parks, BS, ${ }^{a, b}$ Tracy Mathisen, BS, \\ and Debra J. Romberger, MD ${ }^{\mathbf{a}, \mathbf{b}}$ Omaha, Neb
}

\begin{abstract}
Background: Organic dust exposure results in an inflammatory response that attenuates over time, but repetitive exposures can result in chronic respiratory diseases. Mechanisms underlying this modulated response are not clear.

Objective: This study investigated the effects of repeat versus single organic dust exposure-induced inflammatory mediators and protein kinase $\mathrm{C}$ (PKC) activity in monocytes.

Methods: Settled organic dust was obtained from swine confinement facilities. Promonocytic THP-1 cells and human peripheral blood monocytes were pretreated with or without dust extract and then restimulated. Culture supernatants were evaluated for TNF- $\alpha$, IL-6, CXCL8, and IL-10. Responses were compared with endotoxin-depleted dust, LPS, and peptidoglycan. PKC isoform $(\alpha, \delta, \varepsilon, \zeta)$ activation was evaluated by direct kinase activity. PKC isoform inhibitors' effects on TNF- $\alpha$ secretion were studied.

Results: Single exposure to organic dust stimulated monocyte secretion of TNF- $\alpha$, IL-6, CXCL8, and IL-10 compared with unstimulated cells. TNF- $\alpha$ and IL-6 were diminished in pretreated cells restimulated with dust. Secretion of CXCL8 and IL-10 remained persistently elevated. TNF- $\alpha$ responses were retained after marked depletion of endotoxin. Dust exposure induced significant PKC $\alpha, \delta$, $\varepsilon$, and $\zeta$ activation, peaking at 30 to 60 minutes. PKC isoform activation was attenuated in repeat exposed cells. Inhibition of PKC $\alpha$ and PKC $\varepsilon$ reduced dust-induced TNF- $\alpha$ secretion.
\end{abstract}

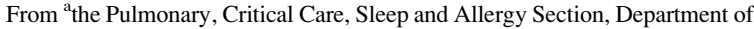
Internal Medicine, University of Nebraska Medical Center; and ${ }^{\mathrm{b}}$ the Omaha Veterans Administration Medical Center.

Supported by the Nebraska Experimental Program to Stimulate Competitive Research Grant (36-5237-2141-001; J.A.P.), the VA Merit Review program (D.J.R.), and the American Lung Association Career Award program (T.A.W.).

Disclosure of potential conflict of interest: S. G. Von Essen has received grant support from the Tuberculosis Curriculum Coordinating Center; is on the advisory board for an Agricultural Health study; and has served as an expert witness in legal cases. The rest of the authors have declared that they have no conflict of interest.

Received for publication October 23, 2006; revised April 23, 2007; accepted for publication April 24, 2007.

Available online June 8, 2007

Reprint requests: Jill A. Poole, MD, Pulmonary, Critical Care, Sleep and Allergy Section, University of Nebraska Medical Center, 985300 The Nebraska Medical Center, Omaha, NE 68198-5300. E-mail: japoole@ unmc.edu.

doi:10.1016/j.jaci.2007.04.033
Conclusion: Repeat organic dust exposure modulated inflammatory mediator production in monocytes independent of endotoxin. The inability of PKC to be reactivated may account for this observation.

Clinical implications: Targeting PKC and specific mediators associated with repetitive organic dust exposure may result in novel therapeutic strategies. (J Allergy Clin Immunol 2007;120:366-73.)

Key words: Monocyte, adaptation, organic dust, swine, cytokines, inflammation, protein kinase $C$

Repetitive organic dust exposure can result in several respiratory health conditions including chronic bronchitis and exacerbation of asthma, resulting in a significant problem for the agriculture industry. ${ }^{1}$ Exposure of naive individuals to organic dust results in fevers, bronchial hyperresponsiveness to methacholine, and increases in proinflammatory mediators in serum and bronchoalveolar and nasal lavage fluid. ${ }^{2}$ Swine farmers also experience an increase in inflammatory cells and cytokines after an exposure challenge, but this response is less pronounced compared with naive subjects, ${ }^{3}$ suggestive of an adaptation response. ${ }^{4}$ Consistent with an adaptation response is the association of a prolonged reduction in serum TNF- $\alpha$ after an exposure challenge. ${ }^{5}$ However, despite an apparent adaptation response, persons repetitively exposed to organic dust experience a high prevalence of respiratory disease and a significant decline in lung function. 6,7

Organic dust is a complex mixture containing particulate matter and microbial-associated components. ${ }^{8}$ Mononuclear phagocytes are key cells that initially respond and are rapidly activated by exposure to inhaled organic dust. ${ }^{9}$ Monocyte/macrophage-derived inflammatory mediators can induce pyrexia, neutrophil recruitment, and activation of airway epithelial cells, and cause direct bronchial hyperreactivity. ${ }^{10,11}$ Of the components in organic dust, endotoxin has been well described for its role as a potent inflammatory stimulus. ${ }^{7,12}$ However, there has not been a consistent association with endotoxin levels and inflammatory outcomes in swine confinement workers. ${ }^{13,14}$ Another bacterial exposure agent detected in swine confinement barns and found to correlate with inflammatory outcomes in exposed subjects is peptidoglycan. ${ }^{15}$ Thus, given the complex nature of organic dust, and given 


\author{
Abbreviations used \\ CXCL8: IL-8 \\ DE: Dust extract \\ PBM: Peripheral blood monocyte \\ PKC: Protein kinase C
}

that the inflammatory response is likely not dependent on 1 specific component but on several microbial agents, studies with organic dust samples are necessary.

Defining the mechanisms underlying the inflammatory response to repeat versus single organic dust exposure may help better explain the development of organic dustinduced diseases and the adaptation-like response. Adaptation/tolerant models have found that a complex, regulated response occurs with single versus repeat stimuli that is dependent on the specific exposure agent. ${ }^{16}$ In repeat organic dust-induced inflammation, these events have not been well defined. The protein kinase $\mathrm{C}$ (PKC) family is an important candidate family of serine/threonine kinases responsible for intracellular activation of diverse signaling pathways. In airway epithelial cells, we have found that organic dust-induced IL-6 and CXCL8 secretion is dependent on PKC activity. ${ }^{17} \mathrm{PKC} \varepsilon$ and $\mathrm{PKC} \zeta$ are also downstream targets of endotoxin signals in monocytes/macrophages, and total PKC activation has been implicated in the endotoxin tolerant/adaptation state. ${ }^{18,19}$ Targeting 1 or several of the PKC isoenzymes could lead to novel therapeutic strategies.

Because organic dust is complex, we hypothesized that repeat versus single organic dust exposure would modulate monocyte inflammatory mediator responses, independent of endotoxin. We further hypothesized that PKC isoform activation would be involved in mediating the modulated response. To test these hypotheses, we compared the inflammatory mediator responses and activation of PKC isoforms in vitro to repeat and single dust exposure in monocytes. We also evaluated the effects on TNF- $\alpha$ secretion in dust-exposed cells pretreated with $\mathrm{PKC}$ isoform inhibitors. Comparisons were made to endotoxin, peptidoglycan, and dust depleted of endotoxin.

\section{METHODS}

\section{Subjects}

Healthy, nonfarming subjects were enrolled at the Veterans Administration Medical Center. Subjects eligible to participate were 18 years of age or older. Peripheral blood was taken with written informed consent before enrollment with a protocol approved by the Institutional Review Board at the Omaha Veterans Administration Medical Center.

\section{Preparation of organic dust extract}

Organic dust was obtained from settled surface dust from 2 different swine confinement animal feeding operation facilities, each having $\sim 500$ to 700 animals. Dust extract (DE) was prepared as previously published. ${ }^{17}$ The amount of endotoxin in the DE was quantitated by using the limulus amebocyte lysate gel clot assay (Cambrex, Walkersville, Md). The mean endotoxin concentration present in a $5 \%$ concentration of DE was $0.24 \mu \mathrm{g} / \mathrm{mL}$ (range: 0.13 $0.35 \mu \mathrm{g} / \mathrm{mL}$ ). The endotoxin concentration (biomarker of exposure) present in the DE is compatible with that found in modern day swine confinement facilities. ${ }^{20}$ Endotoxin was undetectable in the media used. To characterize the DE better, DE was boiled for 10 minutes, cooled to room temperature, and added to media. To assess response of endotoxin-depleted dust extract, the DE was applied to polymyxin B columns (Pierce, Rockford, Ill). The mean endotoxin concentration present and maintained after depletion was $<0.2 \mathrm{ng} / \mathrm{mL}$ in all endotoxin-depleted samples ( $>1000$-fold less endotoxin than in completed DE) as verified at the initiation of the experimental conditions.

\section{Cell preparation}

Promonocytic THP-1 cells were obtained from American Type Culture Collection (Manassas, Va) and maintained in complete RPMI, which consisted of L-glutamine-RPMI 1640 (Life Technologies, Grand Island, NY) supplemented with $10 \%$ heat-inactivated FBS (Invitrogen, Carlsbad, Calif), 2-mercaptoethanol $\left(5 \times 10^{-5} \mathrm{~mol} /\right.$ $\mathrm{L}), 50 \mu \mathrm{g} / \mathrm{mL}$ streptomycin (Invitrogen), and $80 \mathrm{U} / \mathrm{mL}$ amphotericin B (Invitrogen). Log-phase THP-1 cells were used in all experiments.

PBMCs were isolated from heparinized blood samples by density gradient centrifugation over Ficoll-Paque Plus (Amersham Biosciences, Piscataway, NJ). Mononuclear cells were collected, washed with PBS, and suspended in complete RPMI media. Mononuclear cells $\left(2 \times 10^{6}\right.$ cells $\left./ \mathrm{mL}\right)$ were incubated for 2 hours in duplicate in culture medium in 6 -well culture plates at $37^{\circ} \mathrm{C}$ in a $5 \% \mathrm{CO}_{2}$ incubator. The cultures were enriched in peripheral blood monocytes (PBMs) by discarding the medium and washing the wells twice with PBS to remove nonadherent cells. Adherent enriched monocytes were immediately used in the adaptation experiments. At initiation of the human PBM experiments, monocyte yield was $>80 \%$ as determined by Giemsa staining. After the 18-hour pretreatment phase and wash, monocyte yield and viability was $>95 \%$, and on completion of the 5-hour restimulation phase, monocyte yield was $>99 \%$. In all experimental conditions and phases, cells were counted and evaluated for viability by trypan blue exclusion method.

\section{Inflammatory marker assays}

The first set of experiments established a set of conditions to measure organic dust-stimulated TNF- $\alpha$ secretion in cultures of THP1 cells. THP- 1 cells $\left(1 \times 10^{6}\right.$ cells $\left./ \mathrm{mL}\right)$ were incubated with escalating doses of DE $(0.1 \%, 1 \%, 5 \%, 10 \%)$ or media for 5 hours. Cell-free supernatant was subsequently harvested and assayed for TNF- $\alpha$. A similar set of experiments was used with escalating concentrations of endotoxin-depleted DE and boiled DE. Separate time course studies determined that 5 hours postexposure was optimal in eliciting TNF- $\alpha$ secretion.

For adaptation studies, THP- 1 cells $\left(1 \times 10^{6}\right.$ cells $\left./ \mathrm{mL}\right)$ were pretreated by incubating the cells with $\mathrm{DE}(0.1 \%, 1 \%)$ or media. After 18 hours, cells were centrifuged and washed in PBS. Cells were then restimulated at a higher concentration of DE $(5 \%)$ or media. After 5 hours, cell-free supernatants were harvested and assayed for TNF- $\alpha$ secretion. The incubation periods and relative concentration challenges (pretreatment with low dose followed by restimulation with high dose) for the experimental protocol was modified from published endotoxin-tolerant/adaptation studies. ${ }^{16,21}$ A similar set of experiments were completed with endotoxin-depleted DE.

To characterize further the inflammatory response, adherent human PBMs were obtained from healthy subjects $(n=8$ separate volunteers) as described. PBMs were pretreated by incubating the cells with DE $(0.1 \%, 1 \%), \mathrm{LPS}(100 \mathrm{ng} / \mathrm{mL})$, peptidoglycan $(100 \mathrm{ng} /$ $\mathrm{mL}$ ), or media. After 18 hours, adherent cells were washed in PBS and restimulated with DE $(5 \%)$, LPS $(1 \mu \mathrm{g} / \mathrm{mL})$, peptidoglycan $(1 \mu \mathrm{g} / \mathrm{mL})$, or media. The concentration of LPS was a 5-fold higher 


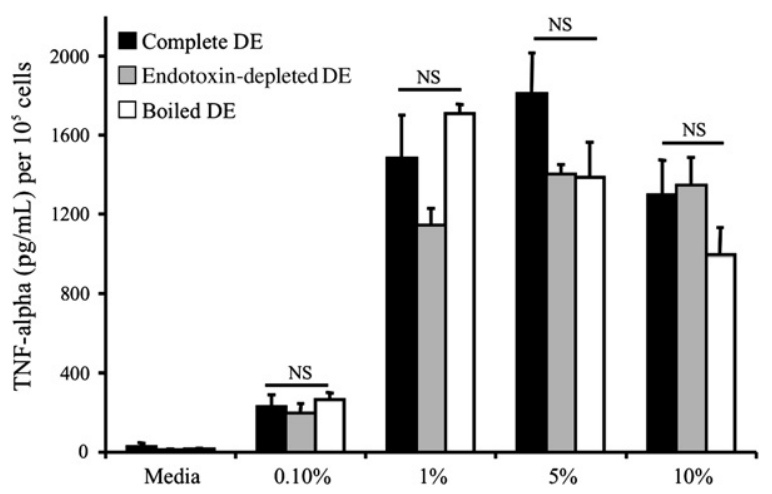

FIG 1. Dose-dependent secretion of TNF- $\alpha$ by THP-1 cells to a 5-hour challenge with complete $\mathrm{DE}$, endotoxin-depleted $\mathrm{DE}$, and boiled $\mathrm{DE}$. Mean results are presented as concentration $(\mathrm{pg} / \mathrm{mL})$ per $1 \times 10^{5}$ cells with SE bars shown $(\mathrm{n}=3)$. ${ }^{*}$ Statistically significant $(P<.05)$. NS, Nonsignificant.

concentration than found in complete DE (5\%). After 5 hours, cellfree supernatants were harvested and stored at $-20^{\circ} \mathrm{C}$ until assayed for cytokine and chemokine secretion. LPS used was from Escherichia coli (O55:B5) purchased from Sigma (St Louis, Mo). Staphylococcus aureus peptidoglycan was from Sigma.

TNF- $\alpha$ levels in culture supernatants were assayed in duplicate and quantified by sandwich ELISA according to the manufacturer's instructions (R\&D, Minneapolis, Minn) with sensitivity of $7 \mathrm{pg} / \mathrm{mL}$. CXCL8 and IL-6 levels in culture supernatants were quantified in duplicate by using sandwich ELISA as previously described, ${ }^{17}$ with sensitivities of 78 and $40 \mathrm{pg} / \mathrm{mL}$, respectively. IL-10 and TGF- $\beta$ levels in culture supernatants were assayed in duplicate and quantified by sandwich ELISA with Quantikine Enzyme Immunoassay kit (R\&D Systems) according to the manufacturer's instructions with sensitivities of 8 and $31.2 \mathrm{pg} / \mathrm{mL}$, respectively. Cytokine/chemokine secretion is reported as concentration $(\mathrm{pg} / \mathrm{mL})$ per $1 \times 10^{5}$ viable cells as determined on completion of the experimental protocol by trypan blue exclusion method.

\section{PKC isoform assay}

To study the role of PKC isoform activation, a radiolabeled $\left[\gamma^{-32} \mathrm{P}\right]$ ATP assay was used. An optimal time course for measuring PKC isoform activity in THP-1 cells was determined by incubating cells $\left(1 \times 10^{6}\right.$ cells $\left./ \mathrm{mL}\right)$ in triplicate with $\mathrm{DE}(5 \%)$ at 15,30 , 60,180 , and 360 minutes. For adaptation studies, THP-1 cells were incubated with or without DE $(0.1 \%, 1 \%)$. After 18 hours, cells were washed with PBS and restimulated with or without DE $(5 \%)$. Cells were harvested for PKC isoform activity after 30 minutes.

Specific PKC isoenzyme activation was determined in crude whole-cell fractions of monocytes for $\mathrm{PKC} \alpha, \mathrm{PKC} \varepsilon, \mathrm{PKC} \delta$, and PKC $\zeta$ because they are known to be expressed in THP- 1 cells. ${ }^{22}$ Cells were fractionated and assayed as previously described. ${ }^{17}$ Briefly, the PKC $\alpha$ assay used $900 \mu \mathrm{mol} / \mathrm{L}$ PKC substrate peptide (Bachem, Torrance, Calif), $12 \mathrm{mmol} / \mathrm{L}$ calcium acetate, $8 \mu \mathrm{mol} / \mathrm{L}$ phosphatidyl-L-serine, $24 \mu \mathrm{g} / \mathrm{mL}$ phorbol 12-myristate 13-acetate, $30 \mathrm{mmol} / \mathrm{L}$ dithiothreitol, $150 \mu \mathrm{mol} / \mathrm{L}$ ATP, $24 \mathrm{mmol} / \mathrm{L}$ magnesium acetate, and $10 \mu \mathrm{Ci} / \mathrm{mL}\left[\gamma_{-}{ }^{32} \mathrm{P}\right] \mathrm{ATP}$ (ICN Biomedicals, Costa Mesa, Calif) in a TRIS-hydrochloric acid buffer $(\mathrm{pH} 7.5)$. PKC $\varepsilon$ and $\mathrm{PKC} \delta$ were assayed as described with specific $\varepsilon$ (Calbiochem, San Diego, Calif) and $\delta$ (Calbiochem) substrate peptides in the absence of calcium in the reaction mixture. PKC $\zeta$ was assayed in the absence of calcium and phorbol ester by using a specific PKC $\zeta$ phosphopeptide substrate (Invitrogen). Kinase activity as counted in nonaqueous scintillant was expressed in relation to total cellular protein assayed and calculated in picomoles of phosphate incorporated per minutes per milligram. Data were reported as fold-increase from baseline: dust-induced kinase activity divided by media alone kinase activity.

\section{PKC isoform inhibition studies}

The effects of PKC isoform inhibition in dust-induced TNF- $\alpha$ secretion in THP-1 cells was evaluated to study further the role of PKC. THP- 1 cells $\left(5 \times 10^{5}\right.$ cells $\left./ \mathrm{mL}\right)$ were preincubated for 1 hour with or without specific PKC isoform inhibitors: PKC $\alpha$ inhibitor, Gö 6976 (1 $\mu \mathrm{mol} / \mathrm{L}$; Calbiochem); PKCE inhibitor, Ro 31-8220 ( $1 \mu \mathrm{mol} / \mathrm{L}$; Sigma); PKC $\delta$ inhibitor, Rottlerin $(1 \mu \mathrm{mol} / \mathrm{L}$; Biomol International, Plymouth Meeting, Pa), and PKC $\zeta$ inhibitor, myristoylated PKC $\zeta$ ( $1 \mu \mathrm{mol} / \mathrm{L}$; Biomol International). Cell cultures were then incubated with or without DE (5\%). After 5 hours, TNF- $\alpha$ was quantified in the supernatants by ELISA as described. There was no difference in cell viability between groups as assessed by trypan blue exclusion method. Mean results of TNF- $\alpha$ secretion were converted to percentage of dust exposure alone-induced cytokine secretion (DE-induced cytokine secretion with inhibitor divided by DE-induced cytokine secretion without inhibitor multiplied by 100).

\section{Statistical analysis}

Data are presented as the means \pm SEMs. Statistics were performed by using 2-tailed nonpaired or paired $t$ tests to determine significant changes among treatment groups.

\section{RESULTS}

\section{Organic dust induces TNF- $\alpha$ secretion independent of endotoxin}

The first set of experiments demonstrated a dosedependent secretion of TNF- $\alpha$ by THP-1 cells exposed to a 5-hour challenge with dust extract (Fig 1). An optimal response was determined at a $5 \%$ concentration with cell viability determined to be $>95 \%$ by trypan blue exclusion method. There was no evidence of cell death at the $0.1 \%$ and $1 \%$ concentration. Significant dose-dependent secretion of TNF- $\alpha$ also occurred in response to endotoxin-depleted and boiled DE (Fig 1), suggesting an endotoxin-dependent response.

\section{Repeat dust exposure diminishes TNF- $\alpha$ secretion in THP-1 cells}

To examine the inflammatory response to single versus repeat dust exposure, THP- 1 cells were pretreated with low concentrations of DE $(0.1 \%$ and $1 \%)$ or media for 18 hours. The cells were then washed and rechallenged with a $5 \%$ concentration of DE or media for 5 hours. There was a significant decrease in TNF- $\alpha$ secretion in a dose-dependent fashion when THP-1 cells were pretreated with DE before restimulation (Fig 2, $A$ ). In addition, this response was retained, but attenuated after marked depletion of endotoxin (Fig 2, B). The decrease in TNF- $\alpha$ secretion was not secondary to diminished cell counts because there were no differences in cell count or viability between 

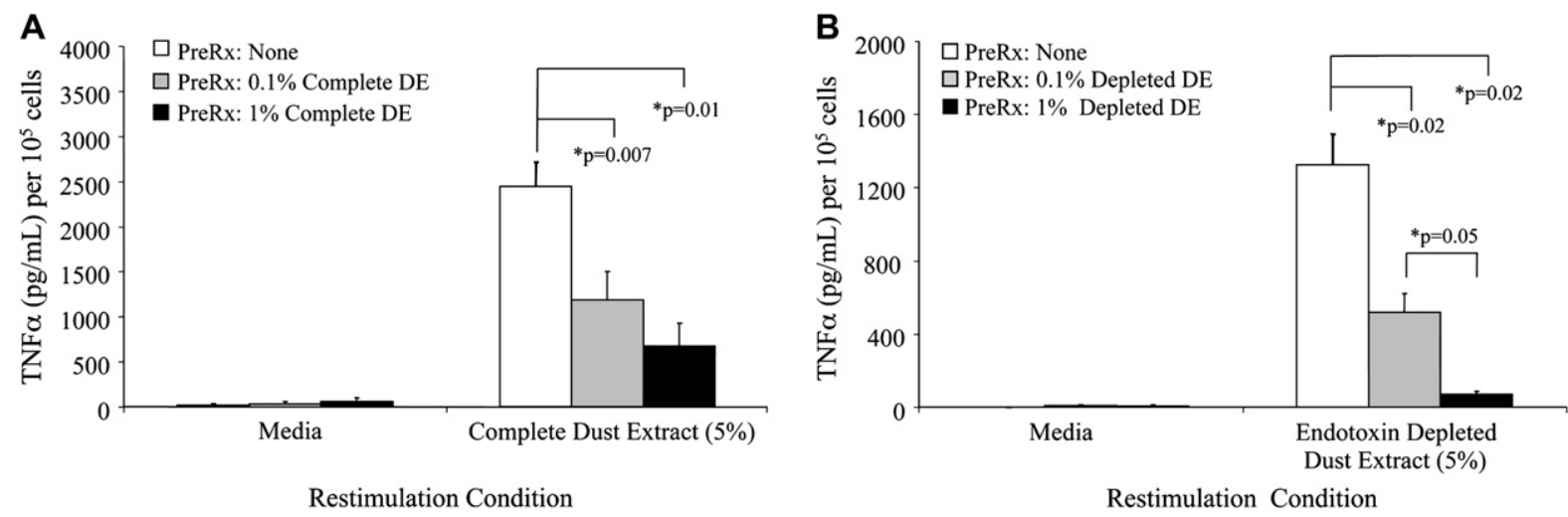

FIG 2. Diminished secretion of TNF- $\alpha$ by organic dust-pretreated THP-1 cells after restimulation. A, Complete DE. B, Endotoxin-depleted DE. THP-1 cells were pretreated with or without DE for 18 hours, then restimulated for 5 hours. Mean results are presented as concentration $(\mathrm{pg} / \mathrm{mL})$ per $10^{5}$ cells with SE bars $\operatorname{shown}(\mathrm{n}=3)$. * Statistically significant $(P<.05)$. PreRx, Pretreatment.

untreated and pretreated cells rechallenged with DE or endotoxin-depleted DE.

\section{Modulated inflammatory mediator response to repeat versus single dust-exposed human PBMs}

To characterize further the inflammatory response to repeat versus single organic dust exposure, human PBMs from separate donors were used $(n=8)$. As described in Methods, enriched PBMs were pretreated with a low concentration of DE or media, then restimulated with a high concentration of $\mathrm{DE}$ or media. In side-by-side experiments, cells were also challenged in a similar manner with LPS and peptidoglycan as important controls and relevant comparisons. We found that monocytes receiving no pretreatment but restimulated with DE 5\% (single exposure model) secreted more TNF- $\alpha(P=.007)$, IL-6 $(P=.001)$, and IL-10 $(P=.047)$ compared with monocytes restimulated with LPS $1.0 \mu \mathrm{g} / \mathrm{mL}$ (Fig 3, $A, B, D$ ). We also found more TNF- $\alpha(P=.001)$, IL-6 $(P=.007)$, and IL-10 $(P=.02)$ secretion with monocytes receiving no pretreatment but restimulated with DE 5\% compared with cells restimulated with peptidoglycan $1.0 \mu \mathrm{g} / \mathrm{mL}$ (Fig 3, A, B, D).

TNF- $\alpha$ secretion was diminished in PBMs pretreated with DE, LPS, and peptidoglycan compared with cells not pretreated after restimulus (Fig 3, A). IL-6 secretion was diminished in a dose-dependent fashion in DE-pretreated PBMs as well as in LPS-pretreated PBMs, but not in peptidoglycan-pretreated PBMs (Fig 3, B). In contrast, CXCL8 levels were not diminished in PBMs pretreated with DE, LPS, and peptidoglycan compared with cells not pretreated after restimulus (Fig 3,C).

IL-10 secretion was persistently elevated in PBMs pretreated with DE, LPS, and peptidoglycan (Fig 3, D). In cells pretreated with DE and then restimulated with DE $(5 \%)$, the secretion of IL-10 was significantly higher compared with cells not pretreated with DE. Interestingly, in monocytes preincubated with DE for 18 hours, washed, but not restimulated, the basal secretion of IL-10 in the culture supernatant significantly increased compared with unstimulated monocytes (Fig 3,D). There was no change in TGF- $\beta$ secretion among any of the treatment conditions (data not included). These studies in human PBMs implicate IL-10 in mediating the modulated inflammatory response to repeat dust exposures.

\section{PKC isoenzymes activated with single dust exposure are attenuated with repeat exposure}

To investigate a possible signaling mechanism, PKC activity was assessed because we have previously found it to be important in modulating dust-induced inflammation in epithelial cells. As shown in Fig 4, dust exposure significantly induced $\mathrm{PKC} \alpha, \mathrm{PKC} \varepsilon, \mathrm{PKC} \delta$, and $\mathrm{PKC} \zeta$ activation in a time-dependent manner in THP-1 cells. All isoforms were rapidly activated, peaking at 30 to 60 minutes postexposure. To determine whether PKC activity was involved in the repeat dust exposure response, THP-1 cells were pretreated for 18 hours with or without $\mathrm{DE}(0.1 \%, 1 \%)$ and then restimulated with or without DE $(5 \%)$ for 30 minutes. PKC $\alpha, \mathrm{PKC} \varepsilon, \mathrm{PKC} \delta$, and PKC $\zeta$ activities were attenuated in cells pretreated with DE compared with cells not pretreated after restimulation (Fig 5). These findings suggest that the inability for PKC to be reactivated is important in the repeat dust-exposed modulated inflammatory response.

\section{PKC $\alpha$ and PKC $\varepsilon$ inhibition reduces dust- induced TNF- $\alpha$ secretion}

To evaluate further the role of PKC isoform activity, the effects of specific PKC isoenzyme inhibition on TNF- $\alpha$ secretion were assessed. Dust-induced TNF- $\alpha$ secretion in THP-1 cells was significantly reduced in cells pretreated with $\mathrm{PKC} \alpha$ and $\mathrm{PKC} \varepsilon$ inhibitors (Fig 6). There was a slight reduction in $\mathrm{TNF}-\alpha$ secretion in cells pretreated with the PKC $\delta$ inhibitor Rottlerin. No significant inhibition was observed in cells pretreated with the PKC $\zeta$ inhibitor myristoylated PKC $\zeta$. TNF- $\alpha$ secretion was also reduced in a similar manner with the PKC $\alpha$ and PKCE inhibitors in PBMCs (data not shown). 
A
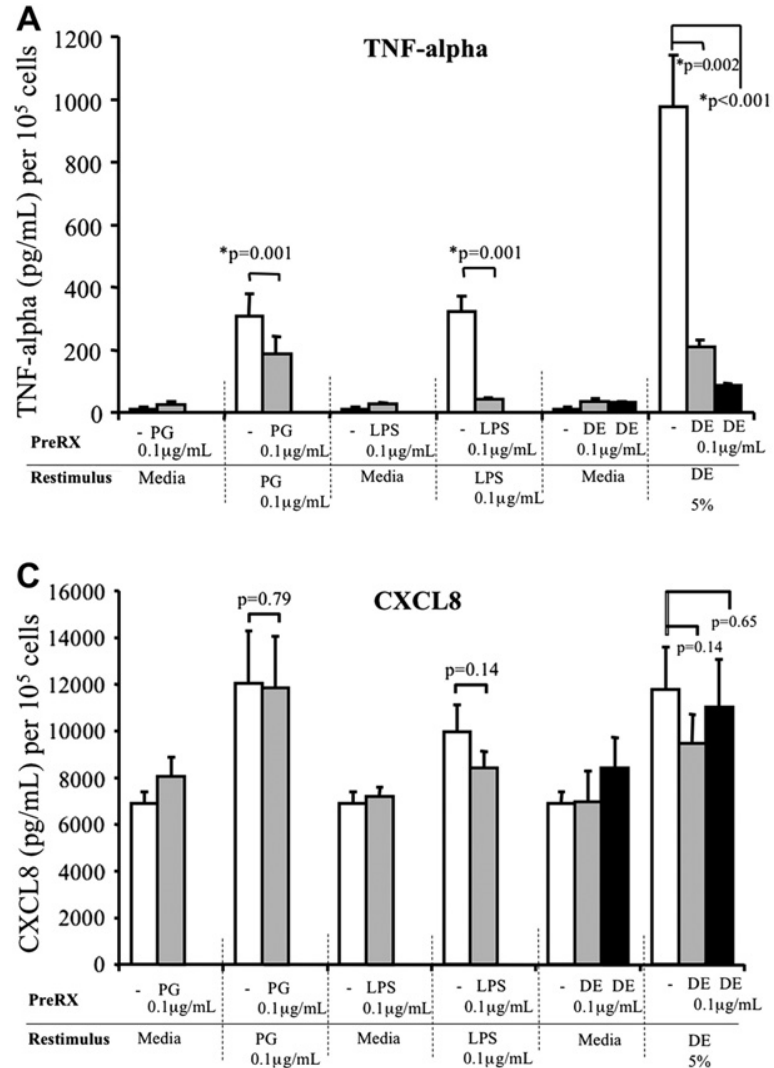
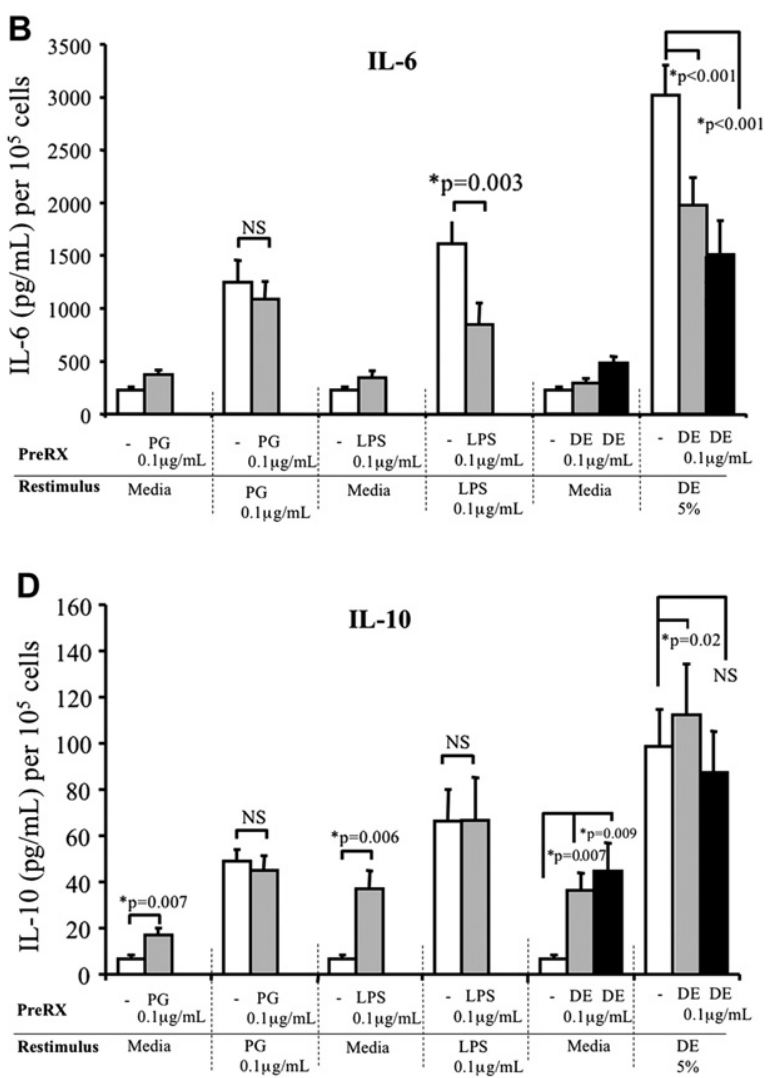

FIG 3. Secretion of inflammatory mediators in human PBMs with peptidoglycan (PG), LPS, and DE. Monocytes pretreated with PG, LPS, and DE for 18 hours, and then restimulated for 5 hours. A, TNF- $\alpha$. B, IL-6. C, CXCL8. D, IL-10. Mean results are presented as concentration $(\mathrm{pg} / \mathrm{mL})$ per $10^{5}$ cells with SE bars shown ( $\mathrm{n}=8$ separate donors). ${ }^{*}$ Statistically significant $(P<.05)$. PreRx, Pretreatment.

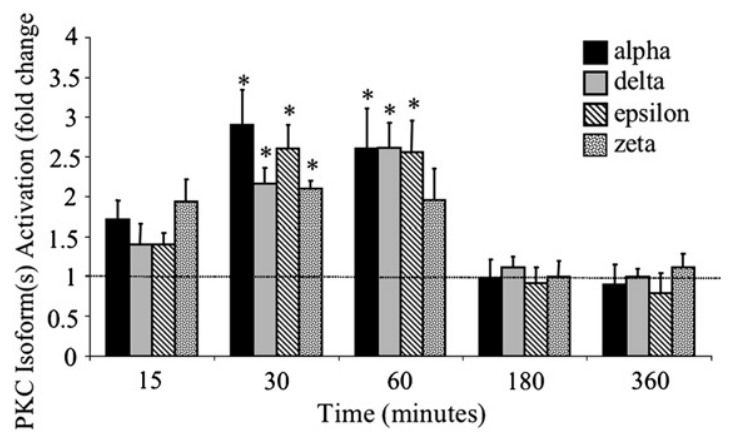

FIG 4. Organic dust-induced PKC isoform activity. THP-1 cells were incubated with or without complete dust extract (5\%) for 15, 30, 60, 180 , and 360 minutes, and then assayed for $\mathrm{PKC} \alpha, \mathrm{PKC} \delta, \mathrm{PKC} \varepsilon$, and PKC $\zeta$. Mean results shown as kinase activity fold increase compared with control media with SE bars $(n=3)$. *Statistically significant compared with control; $P<.05$.

\section{DISCUSSION}

Organic dust exposure has been implicated in increased morbidity and mortality among repetitively exposed subjects. ${ }^{1}$ Whereas the acute inflammatory response to organic dust has been well characterized, little is known about the immunologic mechanisms underlying the response to repeat organic dust exposure. In this study, repeat organic dust exposure modulated inflammatory mediator secretion. Furthermore, several PKC isoforms appear to be important signaling enzymes in organic dust-induced inflammation.

Organic dust from large animal confinement facilities is recognized as a complex mixture of microbial-associated components and particulate matter known to elicit inflammatory responses. ${ }^{8} \mathrm{We}$ found that a single exposure of dust extract from swine confinement barns in monocytes resulted in significant secretion of TNF- $\alpha$. Although attenuated, dust markedly depleted of endotoxin also resulted in high levels of TNF- $\alpha$ secretion. In human monocytes, a 5-fold higher concentration of LPS than that found in the DE $(5 \%)$ was compared in side-by-side experiments, and the DE significantly induced more TNF- $\alpha$, IL-6, and IL-10 secretion. Our findings are consistent with other studies demonstrating that the endotoxin component in swine barn dust does not completely explain the inflammatory cytokine release in cultured airway epithelial cells and whole blood. ${ }^{17,23,24}$ These observations may help explain why association studies fail to consistently link endotoxin and disease manifestation in swine farming 


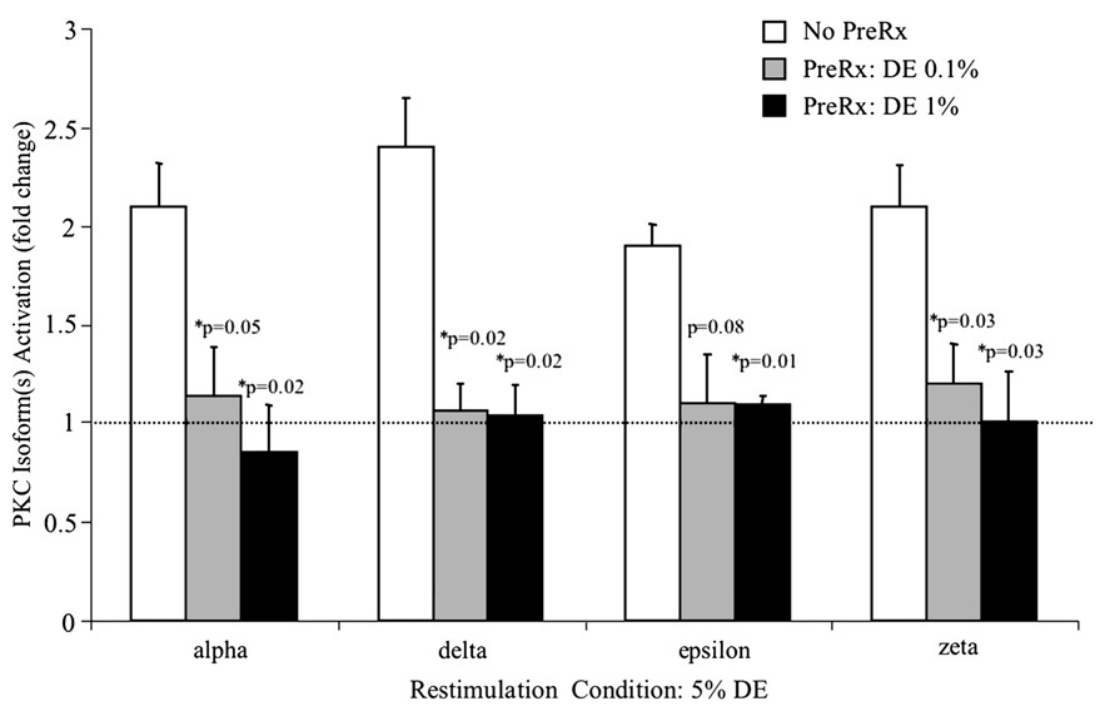

FIG 5. PKC isoform activation in THP-1 cells pretreated with complete DE after restimulation. Cells pretreated with or without DE for 18 hours, then rechallenged for 30 minutes. Mean results shown as kinase activity fold increase compared with control media with SE bars $(n=3)$. Statistical values are based on comparison with cells without pretreatment. ${ }^{*}$ Statistically significant $(P<.05)$. Pre $R x$, Pretreatment.

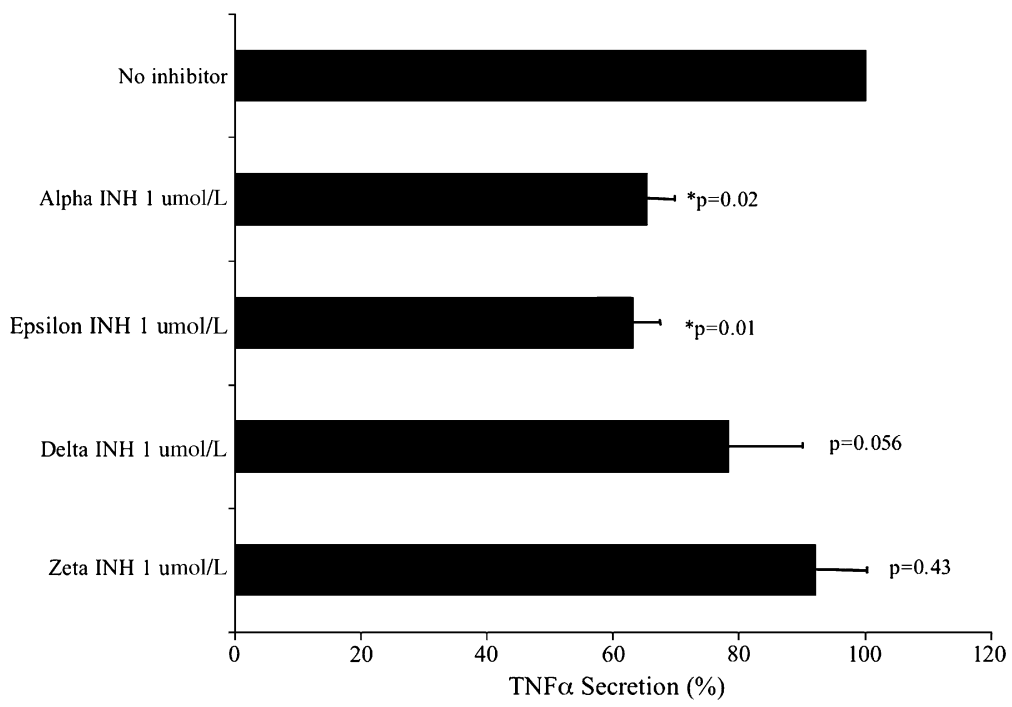

FIG 6. Effects of PKC isoform inhibitors on DE (5\%)-induced secretion of TNF- $\alpha$ in THP-1 cells. PKC inhibitors: $\alpha$ inhibitor, Gö 6976; $\varepsilon$ inhibitor, Ro 31-8220; $\delta$ inhibitor, Rottlerin; $\zeta$ inhibitor, myristoylated PKC $\zeta$. Mean results presented as the percentage of dust-alone TNF- $\alpha$ secretion with SE bars shown $(n=3) .{ }^{*}$ Statistically significant $(P<.05)$. INH, Inhibitor.

environments. Although endotoxin is clearly a potent inflammatory stimulus, it is possible that other microbial components such as peptidoglycan may play a significant role. It is likely that synergy or additive effects occur among the various microbial components and particulate matter in the dust, resulting in disease manifestation. Future investigations into these components are necessary.

To characterize the monocyte response to repeat versus single exposure, modifications in a well established monocyte experimental model were used. ${ }^{16}$ Consistent with the model, we found that pretreatment of human monocytes with lower concentrations of dust resulted in diminished TNF- $\alpha$ secretion on rechallenge with higher dust concentrations. However, depletion of endotoxin from the dust resulted in retained TNF- $\alpha$ responses, suggesting that the adaptation phenotype to organic dust is not entirely dependent on endotoxin.

In addition to $\mathrm{TNF} \alpha$, IL-6 secretion was also diminished in repeat exposed cells. Together, these observations correspond to the clinical adaptation phenotype observed in workers in large animal facilities. In contrast with the reduction in IL- 6 and TNF- $\alpha$, CXCL8 remained 
persistently elevated. CXCL8 is a chemokine considered to be the most important chemoattractant for neutrophils, ${ }^{10}$ and neutrophils have been implicated in the chronic pulmonary disease observed in organic dust-exposed workers. ${ }^{6}$ This finding also demonstrates that the inflammatory response to repeat organic dust exposure is not secondary to global downregulation, and that a persistent inflammatory response may still be occurring.

One possible mechanism to explain the modulated inflammatory response is the action of anti-inflammatory mediators. In our study, IL-10 remained persistently elevated on rechallenge with organic dust in monocytes pretreated with dust extract. Furthermore, a single exposure to dust followed by no further restimulation resulted in increased basal secretion of IL-10. IL-10 has been shown to reduce acute airway inflammatory responses to organic dust exposure in murine models, ${ }^{25}$ and agents blocking IL- 10 result in the reconstitution of TNF- $\alpha$ secretion. ${ }^{26} \mathrm{IL}-10$ also plays a role in the induction and maintenance of tolerance to allergens and other benign bioaerosols in the respiratory tract. ${ }^{10}$ Therefore, the finding of increased IL-10 by monocytes to organic dust would be consistent with the hygiene hypothesis, which proposes that persons raised in farming environments are less likely to develop allergic diseases. However, persistently elevated IL-10 levels in the lung have been associated with increased mucus metaplasia and lung tissue inflammation in mice. ${ }^{27}$ Increased IL-10 levels are also associated with silica-induced chronic lung disease. ${ }^{28}$ Recently, IL-10 has been shown to reduce subepithelial fibrosis in mice chronically exposed to inhaled endotoxin, but resulted in worsening bronchial hyperreactivity. ${ }^{29}$ Thus, the role of IL-10 is complex and requires further investigation in organic dust-induced diseases.

Another possible mechanism by which repeat organic dust exposure may modulate inflammation is PKC activation. In this study, organic dust was a potent stimulus for rapid $\mathrm{PKC} \alpha, \mathrm{PKC} \delta, \mathrm{PKC} \varepsilon$, and $\mathrm{PKC} \zeta$ activation in monocytes, and the inability of PKC to be reactivated may in part explain the modulated immune response. We further observed that PKC $\alpha$ and PKC $\varepsilon$ play a significant role in dust-induced monocyte secretion of TNF- $\alpha$. This finding is important for future therapeutic strategies. However, the inhibitory effect was modest, suggesting that other cell signaling molecules such as mitogenactivated protein kinases and nuclear factor $-\kappa \mathrm{B}$ should be assessed. Other potential targets include Toll-like receptors and the CD14 molecule.

A possible limitation of this study is the focus on monocytic cells. However, we have previously shown that organic dust from swine confinement facilities elicits a IL-6 and CXCL8 response in epithelial cells that is independent of endotoxin. Furthermore, we have also shown that inhibition of total PKC significantly reduces IL-6 and CXCL8 secretion in dust-exposed epithelial cells. However, the effect of repetitive dust-induced inflammation on other cell types needs to be pursued, most likely via animal models.

In conclusion, repeat exposure of human monocytes in vitro to organic dust obtained from swine confinement facilities resulted in modulation of inflammatory mediator responses, which was not completely dependent on endotoxin. This response may be mediated by PKC isoform activity, and targeting these molecules may have clinical implications for organic dust-induced airway diseases. Future in vivo studies are necessary to assess the cytokine responses and intracellular signaling cascade of alveolar macrophages and respiratory epithelial cells after single and repetitive exposure to organic dust environments.

We thank Jane Devasure for assisting in the experiments and Lisa Chudomelka for assistance with manuscript preparation.

\section{REFERENCES}

1. Von Essen S, Donham K. Illness and injury in animal confinement workers. Occup Med 1999;14:337-50.

2. Schwartz DA, Landas SK, Lassise DL, Burmeister LF, Hunninghake GW, Merchant JA. Airway injury in swine confinement workers. Ann Intern Med 1992;116:630-5.

3. Palmberg L, Larsson BM, Malmberg P, Larsson K. Airway responses of healthy farmers and nonfarmers to exposure in a swine confinement building. Scand J Work Environ Health 2002;28:256-63.

4. Von Essen S, Romberger D. The respiratory inflammatory response to the swine confinement building environment: the adaptation to respiratory exposures in the chronically exposed worker. J Agric Saf Health 2003;9:185-96.

5. Hoffmann HJ, Iversen M, Sigsgaard T, Omland O, Takai H, BonefeldJorgensen $\mathrm{E}$, et al. A single exposure to organic dust of non-naive non-exposed volunteers induces long-lasting symptoms of endotoxin tolerance. Arch Allergy Immunol 2005;138:121-6.

6. Spurzem JR, Romberger DJ, Von Essen SG. Agricultural lung disease. Clin Chest Med 2002;23:795-810.

7. Schwartz DA, Donham KJ, Olenchock SA, Popendorf WJ, Van Fassen DS, Burmeister LF, et al. Determinants of lung longitudinal changes in spirometric function among swine confinement operators and farmers. Am J Respir Crit Care Med 1995;151:47-53.

8. Kline JN, Doekes G, Bonlokke J, Hoffman HJ, Von Essen S, Zhai R. Working group report 3: sensitivity to organic dusts-atopy and gene polymorphisms. Am J Ind Med 2004;46:416-8.

9. Brown DM, Donaldson K. Wool and grain dusts stimulate TNF secretion by alveolar macrophages in vitro. Occup Environ Med 1996;53:387-93.

10. Borish L, Steinke JW. Cytokines and chemokines. J Allergy Clin Immunol 2003;111:S460-75.

11. Pennings HJ, Kramer K, Bast A, Buurman WA, Wouters EF. Tumour necrosis factor-alpha induces hyperreactivity in tracheal smooth muscle of the guinea-pig in vitro. Eur Respir J 1998;12:45-9.

12. Reynolds SJ, Donham KJ, Whitten P, Merchant JA, Burmeister LF, Popendorf WJ. Longitudinal evaluation of dose-response relationships for environmental exposures and pulmonary function in swine production workers. Am J Ind Med 1996;29:33-40.

13. Vogelzang PF, van der Gulden JW, Preller L, Tielen MJ, van Schayck $\mathrm{CP}$, Folgering $\mathrm{H}$. Bronchial hyperresponsiveness and exposure in pig farmers. Int Arch Occup Environ Health 1997;70:327-33.

14. Donham KJ, Reynolds SJ, Whitten P, Merchant JA, Burmeister L, Popendorf WJ. Respiratory dysfunction in swine production facility workers: dose-response relationships of environmental exposures and pulmonary function. Am J Ind Med 1995;27:405-18.

15. Zhiping W, Malmberg P, Larsson BM, Larsson K, Larsson L, Saraf A. Exposure to bacterial in swine-house dust and acute inflammatory reaction in humans. Am J Respir Crit Care Med 1996;154:1261-6.

16. West MA, Heagy W. Endotoxin tolerance: a review. Crit Care Med 2002;30(suppl):S64-73

17. Romberger DJ, Bodlak V, Von Essen SG, Mathisen T, Wyatt TA. Hog barn dust extract stimulates IL-8 and IL-6 release in human bronchial epithelial cells via PKC activation. J Appl Physiol 2002;93:289-96.

18. Aksoy E, Goldman M, Willems F. Protein kinase C epsilon: a new target to control inflammation and immune-mediated disorders. Int J Biochem Cell Biol 2004;36:183-8. 
19. Fan H, Cook JA. Molecular mechanisms of endotoxin tolerance. J Endotoxin Res 2004;10:71-84.

20. Dosman JA, Fukushima Y, Senthilselvan A, Kirychuk SP, Lawson JA Pahwa $\mathrm{P}$, et al. Respiratory response to endotoxin and dust predicts evidence of inflammatory response in volunteers in a swine barn. Am J Ind Med 2006;49:761-6.

21. Heagy W, Hansen C, Neiman K, West MA. Evidence for a CD14- and serum-independent pathway in the induction of endotoxin-tolerance in human monocytes and THP-1 monocytic cells. Shock 2003;19:321-7.

22. Schwende H, Fitzke E, Ambs P, Dieter P. Differences in the state of differentiation of THP-1 cells induced by phorbol ester and 1, 25-dihydroxyvitamin D3. J Leuko Biol 1996;59:555-61.

23. Muller C, Larsson K, Grunewald J. Organic dust-induced interleukin-12 production activates T- and natural killer cells. Eur Respir J 2002;20:686-90.

24. Palmberg L, Larsson BM, Malmberg P, Larsson K. Induction of IL-8 production in human alveolar macrophages and human bronchial epithelial cells in vitro by swine dust. Thorax 1998;53:260-4.
25. Quinn TJ, Taylor S, Wohlford-Lenane CL, Schwartz DA. IL-10 reduces grain dust-induced airway inflammation and airway hyperreactivity. J Appl Physiol 2000;88:173-9.

26. Sfeir T, Saha DC, Astiz M, Rackow EC. Role of interleukin-10 in monocyte hyporesponsiveness associated with septic shock. Crit Care Med 2001;29:129-33.

27. Lee CG, Homer RJ, Cohn L, Link H, Jung S, Craft JE, et al. Transgenic overexpression of interleukin (IL)-10 in the lung causes mucus metaplasia, tissue inflammation, and airway remodeling via IL-13-dependent and -independent pathways. J Biol Chem 2002;277:35466-74.

28. Barbarin V, Arras M, Misson P, Delos M, McGarry B, Phan SH, et al. Characterization of the effect of interleukin-10 on silica-induced lung fibrosis in mice. Am J Respir Cell Mol Biol 2004;31:78-85.

29. Garantziotis S, Brass DM, Savov J, Hollingsworth JW, McElvaniaTeKippe E, Berman K, et al. Leukocyte-derived IL-10 reduces subepithelial fibrosis associated with chronically inhaled endotoxin. Am J Respir Cell Mol Biol 2006;35:662-7.

\section{The Journal of Allergy and Clinical Immunology \\ \& \\ Gastroenterology \\ Announce a \\ Shared Science Program}

Several recent articles in Gastroenterology may be of interest to The Journal of Allergy and Clinical Immunology readers. Among them are:

\section{Enhanced Recruitment Of Cx3cr1+ T-Cells By Mucosal Endothelial Cell-Derived Fractalkine In Inflammatory Bowel Disease}

Miquel Sans, Silvio Danese, Carol de la Motte, Heitor S.P. de Souza, Brenda M. Rivera-Reyes, Gail A. West, Manijeh Phillips, Jeffry A. Katz, and Claudio Fiocchi

Gastroenterology, January 2007 (Vol. 132, Issue 1, Pages 139-153)

\section{Soluble proteins produced by probiotic bacteria regulate intestinal epithelial cell survival and growth}

Fang Yan, Hanwei Cao, Timothy L. Cover, Robert Whitehead, M. Kay Washington, and D. Brent Polk Gastroenterology, February 2007 (Vol. 132, Issue 2, Pages 562-575)

To view these and other Gastroenterology articles of interest to The Journal of Allergy and Clinical Immunology readers, visit www.gastrojournal.org/content/shared_science.

This opportunity is made possible through a reciprocal partnership between the journals and their supporting societies, the AGA Institute, and the American Academy of Allergy, Asthma \& Immunology. 